\title{
Yang Zhu - enfant terrible filozofskega daoizma in njegov koncept privatizma
}

\author{
Jana S. ROŠKER*
}

\section{Izvleček}

Yang Zhu, kitajski filozof iz četrtega stoletja pred našim štetjem, se je v zgodovino kitajske filozofije zapisal kot egoističen hedonist, nezmožen krepostnega življenja v skupnosti, ustrojeni po načelih stroge konfucijanske filozofije. Kot takega ga je uradno konfucijansko zgodovinopisje vselej znova ožigosalo za heretičnega misleca, nevrednega položaja resničnega filozofa. Ta članek poskuša zavrniti takšno intepretacijo Yang Zhujeve filozofije in pokazati, da gre pri njegovem idejnem opusu za izjemno egalitarno filozofijo, ki si prizadeva za svobodo, dostojanstvo in osebno integriteto vsakega posameznika v družbi. Clanek izhaja iz predpostavke, da je prav Yang Zhu tisti predstavnik klasičnega daoizma, ki je poskušal v svojem nauku najbolj dosledno uresničiti načelo družbene strpnosti, avtonomije in individualne svobode $\mathrm{v}$ smislu, ki prihaja do izraza $\mathrm{v}$ reku "živi in pusti živeti«. Yang Zhu je pogosto označen kot zagovornik anarhizma in individualizma. Avtorica na podlagi kontekstualne analize kritično preveri to predpostavko in ugotovi, da je za označevanje Yangove filozofije, ki temelji na zaščiti "zasebnosti«, morda najprimernejši koncept "privatizma«.

Ključne besede: Yang Zhu, filozofski daoizem, klasični daoizem, hedonizem, osebna integriteta, avtonomija, individualizem, privatizem

\section{Yang Zhu - Enfant terrible of Philosophical Daoism and His Concept of Privatism}

\begin{abstract}
Yang Zhu, a Chinese philosopher from the fourth Century BCE, has been in the history of Chinese philosophy regarded as a selfish hedonist, unable of virtuous life in community, structured in accordance with rigid Confucian philosophy. As such, the official Confucian historiography has always marked him as a heretic thinker, unworthy of being a real philosopher. The present article tries to reject such an interpretation of Yang Zhu's philosophy and to expose the fact, that his opus should be regarded as an extraordinarily egalitarian philosophy, striking for freedom, dignity and personal integrity of every individual in society. The article follows the presumption, according to which Yang Zhu is the
\end{abstract}

* Jana S. ROŠKER, Profesorica, Oddelek za azijske študije, Filozfoska fakulteta, Univerza v Ljubljani.

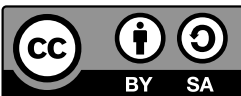


very representative of classical Daoism, who tried in his work to consistently realize the principle of social tolerance, autonomy and individual freedom in the sense of "to live and to let live".

Yang Zhu is often denoted as an advocate of anarchism or individualism. Instead, the author of the present article proposes to apply the term "privatism" to his philosophy, because her contextual analysis has shown that it is a more appropriate and less Eurocentric term.

Keywords: Yang Zhu, philosophical Daoism, classical Daoism, hedonism, personal integrity, autonomy, individualism, privatism

\section{Uvod}

Yang Zhu, pomemben in pri nas še vse premalo znan predstavnik individualističnega anarhizma ali »individualizma«, je živel v obdobju Vzhodne dinastije Zhou (770-221 pr. n. št.). V času svojega življenja je imel kar nekaj vnetih privržencev in njegova filozofija je bila v tistem času precej vplivna, kljub svoji neortodoksnosti - ali pa morda prav zaradi nje. Po legalistični združitvi cesarstva je mojster Yang popolnoma utonil v pozabo. Njegov nauk, ki se zavzema za senzualizem in neposredni čutni užitek kot edini in poslednji smisel življenja, se je moral dostojnim konfucianistom zdeti neznosno amoralističen. Zato ni čudno, da so njegovi nauki ohranjeni zgolj v fragmentarni in nepovezani obliki. Večino teh fragmentov najdemo v 7. poglavju dela Liezi, o njem pa govori tudi Mencij, četudi v zelo jasno ideologizirani obliki (Villaver 2015, 216). Po mnenju znamenitega modernega misleca Hu Shija je Yang Zhujeva filozofija v tem delu tako ali tako ohranjena zgolj po pomoti, namreč "zaradi neumnosti in nepazljivosti Liezijevih ponarejevalcev« (prim. Hu Shi 1984, 176). Tako se imamo »neumnosti in nepazljivosti« končno enkrat zahvaliti za zajeten kupček - zelo nenavadnega in že iz tega razloga nadvse zanimivega - znanja, ki bi sicer za vselej končalo na grmadi državotvorne historiografske morale konfucianističnih cenzorjev. Znani moderni in na Kitajskem še vedno cenjeni zgodovinar filozofije Feng Youlan se s tako razlago ne strinja. (Sicer pa, kdo bi mu to tudi zameril, ko pa Hu po njegovem mnenju s tovrstnim - spet nedostojnim - namigovanjem oziroma podtikanjem po nepotrebnem blati sloves inteligence in moralne neoporečnosti starokitajskih konfucijanskih učenjakov ...) Kakorkoli že, Fengu je ljubša naslednja inačica razlage:

There is reason to suppose, that after death of Lao Tzu, his followers, owing to the different interpretations of the meaning of »Tao«, divided into two diametrically opposite schools, the one represented by Chuang 
Tzu, the other by Yang Chu, just as after the death of Socrates, his followers, owing to the different interpretation of the idea of good, divided into three schools, two of which were diametrical opposite: the Cynics and the Cyreanics. Then came a later Taoist, who, seeing that both schools called themselves Taoists, drew materials from both of them and composed the book, in the name of Lie Tzu, whose existence stil lacks historical proof. (Fung 1953, 65)

\section{Umestitev Yang Zhujeve filozofije v opus filozofskega daoizma}

$\mathrm{V}$ teku stoletij sta se na Kitajskem izoblikovali dve osnovni veji daoizma: filozofska (dao jia 道家) in religiozna (dao jiao 道教). Yang Zhu zagotovo sodi v prvo strujo. Zato si bomo za boljše razumevanje njegove filozofije najprej ogledali temeljne značilnosti filozofskega daoizma, nato pa bomo na kratko opredelili tudi osnovne razlike med obema zgoraj navedenima šolama daoizma.

Podobno kot konfucijanstvo se je tudi filozofski daoizem kot družbeno relevantna miselnost pojavil v obdobju stoterih šol, torej v času postopnega razpada fevdalne družbe konec petega in na začetku četrtega stoletja pr. n. št. Posamezniki, ki so bili siti spletk in boja za oblast in ki so želeli zapustiti svet uradnih hierarhij, so v individualistično-anarhističnem filozofu Yang Zhuju našli prvega preroka osebne svobode in prvega upornika proti najrazličnejšim družbenim prisilam. Yang Zhujevo filozofijo poznamo sicer samo iz žolčnih razprav drugih filozofov, v katerih običajno izražajo svoje ogorčenje nad njegovo »nedopustno« sebičnostjo. Naj bo kakorkoli že, Yang Zhu, ki je zaslovel po svoji radikalni izjavi, češ da za rešitev sveta in vsega človeštva ne bi bil pripravljen žrtvovati niti enega samega lasu s svoje glave, je bil prvi filozof, ki je poskušal relativizirati splošno veljavna merila o vrednosti družbe in posameznika. Problematiko svobode, ki je osrednji predmet njegovih razprav, sta obravnavala tudi oba druga, pri nas bolj znana utemeljitelja daoistične filozofije, Laozi in Zhuangzi.

$\mathrm{V}$ sredičču daoističnega nauka je pojem dao, ki je nastal v veliko zgodnejših obdobjih, torej kar nekaj stoletij pred nastankom stoterih šol klasične kitajske filozofije. Dao je nevidna in neoprijemljiva, a vendar povsod prisotna, večna in vseobsegajoča manifestacija narave oziroma vsega obstoječega. Človek občuti dao v tem, kar ima za njegove zakonitosti: poti zvezd, menjava dneva in noči, letni časi itd. Dao kot simbolično, a tudi dejansko manifestacijo teh zakonitosti najdemo tudi pri konfucijanskih klasikih. Nadaljnja skupna značilnost obeh naukov je, da oba poudarjata organsko povezavo med zakonitostmi zunanje narave in zakonitostmi 
človeškega oziroma družbenega življenja. A medtem ko so konfucijanci v teh zakonitostih videli predvsem naravno dano hierarhijo oblasti in podložništva in so zato v svojih teorijah poudarjali predvsem moralo kot izključno zvezo med naravnimi in družbenimi vsebinami, med metafiziko in pragmatičnim racionalizmom, so daoisti svoj svet dojemali kot naravno dano svobodo. Tako predstavlja konfucijanski dao 道 predvsem etično kategorijo, tisto pot namreč, ki je posamezniku vnaprej dana v socialnem smislu. Pri daoistih je isti pojem uporabljen predvsem kot holistični kozmogonični termin - gre za naravno dano pot (zakonitost) večnih premen vesoljstva in vsega bivajočega.

Etimološki pomen besede dao je torej »pot«. Ta vključuje nenehno gibanje, dinamiko oziroma nenehno spreminjanje, ki hkrati predstavlja tudi način življenja, torej neke vrste ključno metodo ali načelo. Zato ni čudno, da se konfucijanske in daoistične interpretacije tega pojma med seboj bistveno razlikujejo. Dao je za konfucijance tista pot, ki je v svojem globljem smislu predvsem etično vodilo skozi grozljiv pragozd kozmične in družbene nepreglednosti, za daoiste pa tista, ki obstoji sama po sebi, ki je neodvisna tako od čustev kot tudi od razuma, tista pot torej, ki ne potrebuje nobenih dodatkov ali odvzemanj.

Dao je v svojem vseobsegajočem delovanju odločilna in zaokrožena sila, ki v sebi in preko sebe določa vse bivanje, zato se daoistom vsi nasilni posegi v svet zdijo odveč. Ker naj bi se vse stvari razvijale same po sebi, so daoisti tudi najvišjim vladarjem toplo priporočili, naj se čim manj dejavno vmešavajo $\mathrm{v}$ naravni in $\mathrm{s}$ tem tudi družbeni tok življenja. Osrednji pojem daoistične filozofije je koncept nedelovanja (wu wei 無為), ki je kot zrcalna slika konfucijanskega, po kategorijah razčlenjenega sistema odgovornosti, skupaj z njim odločilno vplivala na proces antagonističnega duhovnega razvoja med političnim idealizmom in tisto zavestjo, ki jo v pomanjkanju ustreznega izraza v evropski svet dojemanja žal lahko prevedemo samo $\mathrm{z}$ izmaličujočim izrazom »vdanost v usodo«. Pri tem gre za proces, katerega vpliv je še danes čutiti tako v politični in družbeni stvarnosti Kitajske kot tudi v duši vsakega posameznika. Sicer pa ideal nedelovanja ni pasivne narave, saj omogoča, da se v posamezniku, družbi ali naravi izrazi edina dejavnost, ki zmore ustvariti resnično sožitje med vsemi »desettisočimi stvarmi«. To je »de«, sila oziroma moč naravno dane, osnovne kreposti, ki jo, kot bomo videli v naslednjem poglavju, najdemo že v naslovu osrednjega daoističnega klasika.

$\mathrm{Za}$ daoistično miselnost je tipična tudi odsotnost vsega absolutnega, ki med drugim odseva v samem daotu. Dao je povsod prisoten, vseobsežen, trajen in večen in vendar popolnoma neoprijemljiv, saj dao, ki ga dojamemo, vselej ostaja omejen na naše predstave, naše subjektivno deojmanje in, kar je še posebej vprašljivo, posredovanje. Resnični dao, ki se hkrati nahaja tudi zunaj naše zavesti in celo onkraj 
ločnice med subjektivnim in objektivnim, lahko začutimo $\mathrm{v}$ trenutku večnosti bodisi kot bistvo samega sebe bodisi kot rahel, mavrični most brezimnosti, ki ljudi povezuje $\mathrm{z}$ naravo in med seboj, kadar "pozabijo« na vsa lažna hrepenenja in vse umetne ideale družbenega sožitja.

Zato tudi ideja nedejavnosti nima absolutnega pomena. Notranja svoboda, ki jo dopušča posamezniku, je $\mathrm{v}$ nasprotju $\mathrm{z}$ vsakršnim, tudi najbolj dobronamernim in pragmatičnim totalitarizmom, saj je izvedljiva le v okviru relativizacije vsega obstoječega.

$\mathrm{V}$ tem je tudi vsa umetnost življenja, ki jo najdemo, kadar znamo prisluhniti tudi tišini in ko se posvetimo tistemu, kar je na videz skrito. Zato so se daoisti na vseh področjih življenja zavzemali za tako imenovane "mehke postopke« (rou dao 柔道), ki prihajajo do izraza tudi v ključnih simbolih daoistične filozofije; vodi, ženskosti, otroštvu itd.

Medtem ko se klasiki filozofskega daoizma, h katerim sodijo Yang Zhu, Laozi in Zhuangzi, nikoli niso ukvarjali z nesmrtnostjo, temveč so se prej zavzemali za ideal mirne smrti po dolgem in izpolnjenem življenju, se je od obdobja dinastije Han (206 pr. n. št.-220) naprej vse več daoistov ukvarjalo $\mathrm{z}$ raziskovanjem metod in tehnik za podaljšanje življenja, kar naj bi privedlo do nesmrtnosti. Medtem ko so vsa tovrstna vprašanja poskušali sistematizirati že posamezni filozofi v tretjem stoletju pred našim štetjem, na primer pripadnik šole yinyang Zou Yan, pa se je iz nauka prvega znanega daoističnega alkimista iz obdobja dinastije Han, Liu Shaojuna, razvilo pravo pravcato religiozno gibanje, ki je imelo privržence tako med najvišjimi aristokrati kot tudi med najrevnejšimi ljudskimi množicami.

Seveda so ambicije nege osebnosti in doseganja nesmrtnosti gojili samo tisti daoisti, ki so si to lahko privoščli. Množice revnih kmetov so se morale zadovoljiti s tolažilnim čaščenjem božanstev; obema prej navedenima bogovoma se je ob naraščajočem vplivu budizma $\mathrm{v}$ daoističnem panteonu pridružilo še nepregledno število različnih malikov. Najpomembnejša božanstva so pri tem vselej tvorila trojico »nebo-zemlja-človek«(tian-di-ren 天-地-人), njihov sedež pa je bil tako v notranjosti posameznika kot tudi v središču vesolja. Daoistična religija je prevzela tudi veliko tradicionalnih ljudskih verovanj in obrednih tehnik, kakršen je sistem »vetra in vode» (feng shui 風水). To je specifična kitajska geomantika, ki se je kot veda o kriterijih za celostno in prav vse kozmične dejavnike upoštevajoče določanje najprimernejšega mesta in najprimernejših razmer za postavitev kakšnega objekta ali za izvedbo določene ceremonije vse do danes ohranila v večini vzhodnoazijskih držav.

Daoizem, torej šola, $h$ kateri brezdvomno sodi tudi Yang Zhu, je v vlogi svobodnjaške opozicije proti vladajočemu konfucijanskemu nauku skozi vso zgodovino 
tradicionalne Kitajske ostal vpliven dejavnik družbenega in kulturnega življenja. Posebno pomemben je bil njegov vpliv na razne tajne družbe, ki so pogosto igrale zelo pomembno vlogo pri padcih posameznih dinastij.

Yang Zhujev doprinos $\mathrm{k}$ tej šoli je izjemno dragocen, saj je s svojo - četudi $\mathrm{v}$ svojem času pogosto osovraženo - filozofijo vseskozi opozarjal na nevarnost podjarmljenja človeške osebnosti in na njeno ukalupljanje v standarde, ki koristijo interesom države in njenih oblastnikov.

Njegovo zavzemanje za človeško integriteto so po njegovi smrti pogosto enačili z egoizmom oziroma (vsaj) individualizmom. Vendar je slednji pojem problematičen, če ga obravnavamo s perspektive tradicionalne Kitajske in njene družbene strukture. Že Yang Zhujeva najbolj znana zgodba, ki jo bomo obravnavali v naslednjem poglavju, je dokaz, da lahko pri njegovi filozofiji govorimo prej o zagovarjanju integritete posameznika kot pa individualizma, saj gre konec koncev pri tem terminu za pojem evropskega razsvetljenstva, ki ima v svojem lastnem zgodovinskem kontekstu popolnoma druge konotacije.

\section{Yangova Zgodba o dlaki}

Yang Zhu je skozi vsa stoletja po svoji smrti pa vse do dandanes na Kitajskem užival dvomljiv sloves ekstremnega egocentrika, radikalnega hedonista in asocialnega individualnega anarhista. Vse te nič kaj laskave nazive si je "prislužil «v glavnem z zgodbo dlaki, ki opisuje njegov pogovor z učencem Qin Gulijem:

Qin Guli je vprašal Yang Zhuja: Če bi lahko rešili svet s tem, da bi žrtvovali dlako s svojega telesa, ali bi bili to storili? Yang Zhu je odgovoril, da z eno samo dlako zagotovo ni mogoče rešiti sveta. Vendar je Qin vztrajal:

- Pa denimo, da bi bilo to mogoče. No, kaj bi storili? - Yang Zhu na to ni odgovoril. (cp. Liezi 1998, 217-8)

Za puritanistično moralistične konfucijance je bil Yangov molk že več kot dovolj za obsodbo njegove osebnosti kot nezaslišano pokvarjene, pohujšljive in zato javnemu blagru nadvse škodljive. Te obsodbe, kateri smo lahko priča v večini kasnejših Liezijevih komentarjev, ni moglo omiliti niti nadaljevanje zgodbe, v katerem od ne-odgovora zmedeni Qin poišče dodatno razlago pri starejšem disciplu. Iz nje je jasno razvidno, da Yangova odklonitev ne izhaja iz primitivnega egoizma, temveč iz spoštovanja integritete ter nedotakljivosti človeškega duha in telesa. Kot je razvidno iz interpretacij njegovih učencev, nas njegova Zgodba o dlaki nauči naslednjega: Če nikomur ne bo skrivljen niti en las na 
glavi, in če si nihče ne bo aktivno prizadeval za dobrobit sveta, bo svet vladal samemu sebi. (ibid., 219)

$\mathrm{Z}$ drugimi besedami: vsak naj se briga predvsem zase, ne da bi karkoli jemal drugim in ne da bi jim karkoli dajal. Če bomo vsi zadovoljni s tem, kar imamo, bomo vsi srečni in s tem bomo še najbolj prispevali k blagostanju družbe in vsega sveta.

Namesto izvajanja izpraznjenih ritualov, ki naj bi vodili h krepostnemu življenju, in namesto uklanjanja ter poslušnosti oblastem se je Yang zavzemal za egalitarno brezvladje. Bolj kot intencionalne, pogosto prikrito nasilne družbene aktivnosti, ki po njegovem mnenju vodijo bolj k škodi kot h koristim, ga je zanimalo nedelovanje (wu wei 無為) v smislu sledenja naravnemu teku življenja.

Yangovo zavzemanje za »ohranitev celovitosti naravnega življenja« in za »ohranjanje avtentičnosti individualnega sebstva (prim. ibid.) lahko razumemo v povezavi z njegovo filozofijo telesa, $v$ kateri trdi, da je razumno zadovoljevati človeške potrebe in želje, kajti le na ta način bomo dosegli ravnovesje v ekonomiji energij, ki so temeljnega pomena za ohranitev celovitosti človeškega življenja.

\section{Avtonomija posameznika, pravična družba in vprašanje nesmrtnosti}

Vsekakor je bil Yangov nauk eden redkih ohranjenih filozofij, ki so se v kriznih tranzicijskih časih obdobja Vojskujočih se držav (Zhan guo, 475-221 pr. n. št.) zavzemale za osebno svobodo posameznika. Samovoljnost oblastnikov in njihove morale je šla Yangu očitno precej na živce: »S kaznimi in pohvalami se ljudem vse mogoče prepoveduje, po drugi strani pa se jih priganja; vrednotenje in zakoni prihajajo in se spet zamenjajo, tako da so ljudje neprestano zmedeni in nemirni.« (ibid., 208)

Kot pravi klasični daoist je tudi on izhajal iz holističnega pogleda na svet; hlepenje po nesmrtnosti je videl kot slepo ulico na poti ozaveščenega človeškega življenja. Slednje je namreč videl kot del večnih kozmičnih premen, v sklopu katerih je tudi smrt enakovredna življenju; še več, šele smrt je pravzaprav tista, v kateri postanejo vsa bitja $v$ svojih medsebojnih odnosih takšna, kot v resnici so, namreč enaka in enakovredna, neobremenjena $\mathrm{z}$ negotovimi in minljivimi postulati moralnih in političnih položajev.

Yang Zhu pravi: To, v čemer se obstoječe razlikuje, je življenje. To, v čemer si je vse enako, je smrt. $V$ življenju so modreci in bedaki, bogati in reveži, v tem je različnost. $V$ smrti pa postanejo vsi zgolj smrdeči, gnijoči kosi mesa. V tem je enakost. (ibid., 209) 
Tudi Yangovi fragmenti, ki opisujejo to neločljivo povezanost bivanja in nebivanja, so običajno napačno interpretirani kot poveličevanje smrti in skrajni nihilizem. Vendar tudi ta splošno razširjeni predsodek ne drži; kot je razvidno iz naslednjega citata, Yang ni zanikal vrednosti človeškega življenja, ampak ga je zgolj vrednotil kot del vseobsežne relativizacije stvarnosti, v kateri je smrt enakovredna oblika pojavnosti kot življenje. Ko ga eden njegovih učencev, kateremu je ravnokar postalo jasno, da življenje kot tako nima prav nikakršnega posvečenega, višjega smisla, vpraša, ali potem mar ni bolje čimprej umreti in si morda celo sam vzeti življenje, ga Yang Zhu poduči o tem, da je življenje samo po sebi - torej življenje brez visokoletečih, višjih ciljev - edina prava vrednota. To vrednoto moramo sprejeti in spoštovati tako, kot sprejemamo in spoštujemo smrt, zakaj oboje je del naravno pogojena krogotoka bivanja. Če že živiš, se ne obremenjuj s tem in pusti življenju prosto pot. Raziskuj njegova poželenja in radosti ter mirno počakaj na smrt. Ko bo ta enkrat prišla, pa se ti tudi z njo ni treba obremenjevati. Pusti ji prosto pot in raziskuj, kam te bo odpeljala, dokler ne bo vsega konec. Potem pa tako in tako ne bo več nikakršnih obremenitev in vse bo šlo svojo pot. Čemu bi torej hotel pospešiti ali upočasniti tok življenja? (ibid., 217)

\section{Predsodki o Yangu kot egoističnem hedonistu}

Predsodek o njegovem hedonizmu izvira iz njegove skeptične naravnanosti do vrednot, ki so ljudem posredovane skozi splošno veljavne moralne postulate. $\mathrm{V}$ konfliktnih obdobjih, ki so jih pogojevali spori in hegemonistične težnje posameznih fevdnih oblastnikov in njihovih dvornih ideologov, od katerih je vsak razglašal svojo resnico kot edino veljavno, je ta filozof očitno prišel do zaključka, da splošno veljavna resnica $\mathrm{v}$ smislu absolutnega osmišljenja življenja ne more obstajati. Edini konkretni smisel, ki nam kot ljudem, ujetim v bežni trenutek minljive eksistence, preostaja, je prizadevanje za čim večjo zadovoljnost. Zato je Yang zagovornik uživanja lepote življenja, dokler to traja.

Naj uho posluša, kar želi slišati; naj oko vidi, kar želi gledati; naj nos zavoha, kar želi vohati; naj usta povejo, kar žele govoriti, naj si telo odpočije in duh naj počne, kar se mu zahoče. Uho rado posluša prijetne melodije. Če se mu tega ne dovoli, potem je to zame nasilje nad sluhom. Oko rado gleda lepoto elegance in čutnosti. Če se mu to prepove, potem je to zame nasilje nad vidom. Nos rad voha vonjave cretja. Če se mu to ne omogoči, potem je to zame nasilje nad vonjem. Usta rada povedo, kaj je prav in kaj ne. Če se jim to prepove, potem je to zame nasilje nad modrostjo. Telo si rado odpočije v prijetnem udobju lepote; če se mu tega ne dovoli, potem je to zame nasilje 
nad primernostjo. Duh si želi sprostitve in če se mu to ne omogoči, potem je to zame nasilje nad samoumevnostjo. Vsa tovrstna nasilja so razlogi muk in trpljenja. Komur se posreči odstraniti te razloge muk in trpljenja ter tako v miru dočakati svojo smrt, ta po mojem mnenju živi v skladu $\mathrm{z}$ nego svoje osebnosti, pa tudi če živi samo dan, mesec, leto ali deset let. Kdor pa ostaja ujet $\mathrm{v}$ te razloge muk in trpljenja, je obsojen na klavrno životarjenje, pa četudi bo morda dolgo živel. Tudi če bo (takšno životarjenje) trajalo sto, tisoč ali deset tisoč let, to zame ni nega osebnosti. (ibid., 211)

Predsodek hedonizma je po vsej verjetnosti napačen tudi zaradi tega, ker Yang resničnega uživanja življenjskih radosti ne enači s kopičenjem materialnih dobrin ali politične oblasti, temveč $\mathrm{z}$ osebno avtonomijo $\mathrm{v}$ smislu občutenja skladnosti s samim seboj.

Ljudje se potegujejo za nično, hipno minljivo slavo in si prizadevajo za odvečne časti, ki naj bi jih preživele. Tako v bistvu ostajajo osamljeni. Budno pazijo na to, kar vidijo in slišijo ter si prizadevajo za vrednostne sodbe, ki bi bile v prid njihovemu telesu in duhu. Pri tem pa izgubljajo najdragocenejše trenutke sedanjosti in se ne znajo niti trenutka prepustiti svojim resničnim občutkom. Le v čem se sploh razlikujejo od kaznjencev v verigah? (ibid., 208)

Tako kot sam nikomur ne vsiljuje svojega mnenja, tudi zase zahteva pravico do uresničitve svojih življenjskih idealov in svoje "poti« bivanja. Prej bi lahko torej rekli, da je Yang tisti predstavnik klasičnega daoizma, ki poskuša v svojem nauku najbolj dosledno uresničiti načelo strpnosti in individualne svobode $\mathrm{v}$ smislu "živi in pusti živeti«. Seveda pa nosi prav to načelo v svoji srži libertaren politični naboj, kakršnega konfucianisti nikakor niso mogli tolerirati.

Prvemu kitajskemu anarhistu, čigar dela so ohranjena, se torej ni godilo prav nič bolje kot vsem drugim, ki so živeli za njim: državotvorne ideologije oblastnikov so jih vselej pošiljale »na smetičča zgodovine«. Tako kasneje tudi Mencij, eden najpomembnejših Konfucijevih naslednikov, Yang Zhuja označi za nekakšno zver v človeški podobi: »Gospod Yang je bil egoist, torej ni priznaval vladarjev. (...) Kdor ne priznava očetov ali vladarjev, pa je tak kot divje zveri.« (Mengzi 1997, 109)

\section{Znanje in učenje}

Morda je Yangovo poudarjanje avtentičnosti individualnega sebstva bolje razumljivo bralcem in bralkam enaindvajsetega stoletja. Ta starokitajski filozof nas 
namreč v marsičem spominja na moderne mislece, ki se zavzemajo za avtonomijo posameznika in njegovo zavračanje zunanjih determinacij kot osnovo avtonomne družbe. Tako razumljena avtonomija predstavlja spontan razvoj lastne narave narave namreč, ki ni podrejena ali opredeljena $\mathrm{z}$ zunanjimi entitetami, ne glede na to, ali so te realne ali zgolj ideali. Avtonomija, za kakršno se je zavzemal Yang Zhu, je opredeljena zgolj z lastnim, intimnim sebstvom posameznika. $V$ tem pogledu se bistveno razlikuje od Kantovega koncepta avtonomije, ki pozicionira norme skupnosti nad svobodno voljo posameznika. S takšno idejo avtonomije je Yang poudaril razlikovanje med »tistimi, ki pobegnejo« (dun ren 頓人) in onimi, ki se znajo resnično "prilagajati« (shun ren 順人). Medtem ko je v prvih videl ljudi, ki beže pred svojim lastnim sebstvom in svoje življenje prepuščajo na milost in nemilost zunanjim faktorjem, so bili slednji zanj resnično ozaveščene osebe, saj ne sledijo slepo zunanjim vrednotam in svobodno uživajo avtentičnost svojega življenja, ki je neločljivo povezano $z$ avtonomijo lastnega sebstva (prim. Liezi 1998, 112).

Yang je verjel, da se je človeški intelekt razvil zaradi biološke šibkosti ljudi in iz te šibke biološke opredeljenosti naj bi ljudje uporabljali stvari za vzdrževanje in gojenje lastne narave. $\mathrm{Na}$ ta način naj ljudje razvijajo svoj intelekt brez odvisnosti od fizične moči (ibid.).

$\mathrm{Na}$ tej osnovi je Yang Zhu razvil tudi svojo filozofijo učenja. Pri tem je izhajal iz predpostavke, po kateri je življenje osnovna vrednota. Če se pustimo zavajati prevelikemu številu različnih struj učenja, se nam lahko zgodi, da se bomo v njih izgubili in naša zmedenost bo privedla do tega, da bomo izgubili sami sebe. To si lahko ponazorimo z naslednjim Yangovim citatom, katerega najdemo v Liezijevem poglavju Shuofu: »Kadar je preveč razpotij, ne bomo našli izgubljene ovce. In kadar je preveč različnih učenj, bo učenec izgubil samega sebe.« (ibid., 254)

Zato Yang v središče svoje teorije učenja postavlja avtentičnost življenja (Emerson 1996, 540). Njegova pragmatična vizija učenja temelji na učenju za ohranjanje življenja ter življenjskega razvoja $\mathrm{v}$ skladu $\mathrm{z}$ osebno integriteto, $\mathrm{v}$ kateri je videl najvišjo vrednoto človeškega bivanja.

\section{Zaključek}

Analiza Yangovih citatov je pokazala, da je pri njegovi filozofiji problematično govoriti o individualizmu, saj gre pri tem za koncept evropskega razsvetljenja, katerega pomenske konotacije so popolnoma drugačne od tistih, ki se nanašajo na pojme, ki so v središču Yangove filozofije. Pri individualizmu gre za pojem, ki nastopa kot negacija ali protislovje kolektivizmu ali vsakršnemu tipu komunitarnosti oziroma 
absolutne prioritete skupnosti. Kot smo videli v gornjih besedilih, pa je v ospredju Yangove filozofije zgolj spoštovanje človeške osebnosti kot take. Zavzema se za priznavanje splošnega človeškega dostojanstva in integritete. Ta je mogoča zgolj na osnovi nevmešavanja drugih, torej možnosti zasebnosti. Iz tega razloga je zagotovo primerneje, če Yangovo filozofijo označimo s terminom privatizem, kot da jo označujemo za individualistični diskurz.

\section{Viri in literatura}

Emerson, John. 1996. "Yang Chu's Discovery of the Body." Philosophy East \&' West 46 (4): 533-66.

Forke, Alfred. 1934. Geschichte der alten chinesischen Philosophie (I.). Hamburg: R. Oldenbourg Verlag.

Fung, Yu-lan. 1953. A History of Chinese Philosophy, prevedel Derk Bodde. New Jersey: Princenton University Press.

Harbsmeier, Christoph. 1989. "Marginalia Sino-logica."V Understanding the Chinese Mind - The Philosophical Roots, uredil Robert E. Allinson, 125-66. Oxford, New York: Oxford University Press.

Hu, Shi. 1984. Zhongguo zhexue shi da gang 中国哲学史大纲 (Oris zgodovine kitajske filozofije). Beijing: Shangwu yinshuguan.

Liezi. 1998. Liezi 列子 (Mojster Lie), uredil in komentiral Yang Hong. Lanzhou: Gansu minzu chuban she.

Liu, Xiaogan. 1988. "On the Concept of Naturalness (Tzu-Jan) in Lao Tzu's Philosophy." Journal of Chinese Philosophy 25 (4): 422-45.

Mengzi. 1997. Mengzi 孟子 (Mojster Meng/Mencij)), uredil in komentiral Liang Haiming. Shenyang: Liaoning minzu chuban she.

Rošker, Jana. 2006. Iskanje poti-spoznavna teorija v kitajski tradiciji, 1. del: Od protokonfucijanskih klasikov do neokonfucijanizma dinastije Song. Ljubljana: Znanstveni inštitut filozofske fakultete (zbirka Razprave).

Villaver, Ranie. 2015. "Does Guiji Mean Egoism?: Yang Zhu's Conception of Self." Asian Philosophy 25 (2): 216-23. 